\title{
$\underline{\text { RTAs and South Asia: Options in the Wake of Cancun Fiasco }}{ }^{*}$
}

\author{
by
}

\author{
Pradeep S Mehta and Pranav Kumar ${ }^{1}$
}

\section{Introduction}

Ever since the collapse of Cancun Ministerial and the US Trade Representative Robert Zoellick's reiteration to go for bilateral and regional trade agreements (RTAs) in a subsequent press conference, the debate on multilateralism vs. regionalism got a fresh impetus. It is being widely feared that the collapse of WTO trade talks may shift nations' focus to bilateral or regional pacts.

Already, the formation of the WTO did not halt the proliferation of new RTAs. There has been an enormous increase in Preferential Trade Agreements (PTAs) in the last twenty years. In fact, RTAs legitimacy is well recognised under GATT/WTO. By their very nature, such arrangements favour imports from members of the grouping and discriminate against imports from other countries. This departure from the MFN principle is permitted by Article XXIV of the GATT.

As of March 2003, only four WTO Members: Hong Kong, China; Macao, China; Mongolia, and Chinese Taipei were not parties to a regional trade agreement. With the sole exception of Mongolia, these WTO Members are all engaged in negotiations on preferential agreements. At present, preferential regional trade agreements account for 43 per cent of world trade, and this is expected to increase to 55 per cent by 2005 if all the RTAs currently in the pipeline are realised (OECD, 2003).

The growing popularity of RTAs has also ignited South Asian countries to create a South Asian Preferential Trade Area (SAPTA). Though South Asia is a geographically integrated region, the economic integration level is still low despite a number of initiatives taken by the various stakeholders. The SAPTA was formed way back in 1993, but in true sense it remains a non-starter.

Hence, the fear of a sudden spurt in RTAs is little unwarranted. The main concern is not their increase but whether growing regionalism and its further deepening and widening in the wake of poor progress of trade talks under the WTO can undermine the multilateral trading system. Moreover, the Cancun fiasco has further strengthened the belief of those who are ardent advocate of "regionalism could be building blocks of future multilateralism".

Supporters of RTAs maintain that these agreements have enabled countries to liberalise trade and investment barriers to a far greater degree than multilateral trade negotiations allow. Proponents also argue that regional agreements have gone beyond trade liberalisation, taking important steps toward harmonising regulations, adopting minimum standards for regulations, and recognising other countries' standards and practices' — trends that enhance market access (World Bank 1999/2000).

\footnotetext{
* Paper presented to international conference to mark 10 years of ASARC (Australia South Asia Research Centre), 27 \& 28 April 2004, University House, The Australian National University, Canberra.

${ }^{1}$ Pradeep S. Mehta is the Secretary General of CUTS-International and Pranav Kumar is working as a Policy

Analyst with the CUTS Centre for International Trade, Economics \& Environment, Jaipur, India.
} 
While the renewed momentum for multilateral trade liberalisation and rule making launched at Doha could have helped reduce the risks of regionalism being pursued as a preferred course, but many trade experts are of the view that the failed ministerial at Cancun may force WTO members to place an even greater emphasis on regional initiatives. The USA has made it that it will now redouble efforts to sign bilateral and regional free trade agreements, which are easier to negotiate than WTO agreements.

The purpose of this paper, therefore, is to systematically address the situation in general and with emphasis on South Asia if the failed trade talks at Cancun throw weight behind the formation of more and more bilateral and regional trade treaties. Should they make a renewed effort to kick-start SAPTA? Should they look eastward and try to cooperate more with ASEAN and other East Asian economies? Should they further deepen trading relations with their traditional partners - the EU and US?

This paper contains six sections (including introduction). Section II provides a quick recap of the series of events, which resulted in Cancun debacle. Section III takes into account the proliferation of RTAs over the last two decades, change in US' approach towards regionalism, further deepening and widening of EU and formation of Asia Pacific Economic Cooperation. Section IV in very brief follows the development since the Cancun collapse, the US' efforts to follow bilateral path in FTAA negotiations and India's "Look East” policy. Section V analyses the reasons behind low intra-regional trade. Section VI makes a comparison of intra-SAARC trade with other Southern RTAs, Finally the paper ends with looking into the possible options for South Asia in the post-Cancun scenario.

\section{Revisiting Cancun}

Before discussing the post-Cancun scenario, let us have a quick recap of the series of events, culminating into the "Cancun catastrophe". Like Uruguay Round of trade negotiations and previous ministerial meetings, Cancun was also no exception as far as agriculture playing the spoilsport is concerned. First, it caused serious crisis during the Uruguay Round, causing undue delay in the conclusion of the Round. As per the original schedule, the Uruguay Round was to be completed by 1990, but it got extended by three years and finally concluded in 1993. The second time, at Seattle, talks failed mainly because there were serious differences over liberalisation in agriculture. Labour standards, however, was made the scapegoat. And finally, at Cancun, it was agriculture once again. However, this time the blame was passed on to the Singapore issues, especially investment.

Agriculture dominated the first three days of the negotiations. The tug-of-war between the G$20^{2}$ combine and the European Union (EU) over farm subsidies virtually overshadowed all other issues, including the Singapore ones. Both, the EU and the US, tried their best to break this alliance. But when they did not succeed, they resorted to the "Plan B" of their strategy, i.e. antagonising developing countries to the extent that the Ministerial collapses. The inclusion of Singapore issues in the second revised ministerial draft (the first during the

\footnotetext{
${ }^{2}$ The group was formed pre-Cancun as the G-20. It included Argentina, Bolivia, Brazil, Chile, China, Colombia, Costa Rica, Cuba, Ecuador, El Salvador, Guatemala, India, Mexico, Pakistan, Paraguay, Peru, Philippines, South Africa, Thailand and Venezuela. At Cancun, Egypt, Nigeria and Indonesia joined, while El Salvador withdrew.
} 
ministerial), particularly investment, was a part of this strategy. It was a trap, in which the developing countries fell easily.

Following the failure of the EU and the US in splitting the G-20 alliance, the way the negotiations were conducted gives enough indication that the course of events was fixed in advance by the developed countries, especially the US. The delay in bringing in the second revised draft ministerial declaration, tying up of investment with agriculture and the final hasty wrap-up of talks by the Chairman are some of the links in the chain of events that leave a trail of unanswered questions and, therefore, call for a clarification.

Last time, at Doha, when the developed countries were determined to launch a new round of trade negotiations, the ministerial was extended by a day to arrive at a consensus. But in sharp contrast, in Cancun, when the developing countries, led by G-20, were successful in putting the developed countries in the dock on agriculture subsidies issue, the latter called a halt on the ministerial itself.

Why the delay in bringing out the revised draft ministerial declaration? The text was released at noon on $13^{\text {th }}$ September and in the afternoon the next day; the Chairman announced, "collapse" of the Ministerial. Less than 24 hours were given to reach a consensus on such contentious issues as investment, competition, trade facilitation and transparency in government procurement. Was the Chairman not aware that in seven years (since the Singapore Ministerial of 1996), both protagonists and antagonists could not budge an inch from their original positions? Then, how did he expect members to arrive at a consensus in less than 24 hours?

If we recall the Doha Ministerial, 2001, the revised draft came out on $13^{\text {th }}$ November and the Ministerial concluded on the $15^{\text {th }}$. So, three full days were devoted to negotiations before the final consensus. At that time, developed countries had a clear interest in making the Ministerial successful, because, they were interested in launching a new round of trade negotiations, while environment was also part of the agenda and more importantly, new issues were included in the Doha Work Programme. So, they did everything - from armtwisting to giving sops to least developed countries (LDCs).

In the revised draft, the quid pro quo between investment and agriculture was simply unexpected and, of course, deliberate. There was never any talk about linking investment with agriculture. If at all there was a talk of quid pro quo, it was vis-à-vis investment and mobility of labour. As for the new issues, some trade analysts were hoping to strike a compromise on competition rather than on investment. A consensus on investment was beyond anybody's imagination. Furthermore, on investment, there is no unanimity even among EU member-nations or their businesses.

Why investment was included in the revised draft declaration? One answer could be that since the G-20 was acting tough on agriculture, the EU wanted to counter it by pushing investment on to the agenda. The second possibility was that since investment was the most contentious Singapore issue, it was selected as the trade-off issue only to antagonise developing countries purposely to guide the talks to the failure zone. And the gambit paid off. 


\section{RTAs: Going Parallel With Uruguay Round and WTO}

The global trading system has seen a sharp increase in regional trade agreements over the past two decades. According to World Trade Report 2003 of the WTO, a total of 259 RTAs had been notified to the GATT/WTO by the end of December 2002, although only 176 RTAs are currently in force. An additional 70 RTAs are estimated to be operational although not yet notified and about 70 are under negotiation ${ }^{3}$.

This new wave of regionalism is not new. It has been a continuing part of the post-World War II trade landscape. However, there are three distinctive features of this trend of 'new' regionalism, which have been experienced in the decades of 1980s and 1990s. Firstly, the conversion of US to the regional approach. Secondly, the EU has further deepened and widened its economic integration. Finally, Asia Pacific Economic Cooperation formed in 1989 as the first intergovernmental arrangement in the Asia-Pacific region, with a timeline of completing their integration by 2020 .

\section{III.1 US' Conversion to FTAs, EU Widening and Formation of APEC}

While the recent rapid growth of RTAs began in the 1990s, the seeds of the development were arguably sown in the 1980s. Part of the impulse towards regionalism was driven then by the seemingly bleak prospects for progress on the multilateral agenda in the wake of the inconclusive 1982 GATT Ministerial meeting. Moreover, Western Europe was continuing its moves towards deeper and broader regional integration. Highly significant also was the decision of the United States to explore the preferential approach to trade. Prior to this, the United States had relied almost entirely on the GATT and the MFN principle to define its trade relations with other nations (WTO 2003).

The United States signed its first free trade agreements (FTAs) in 1985 with Israel and then with Canada in 1989. Afterwards, the US, Canada, and Mexico formed the North American Free Trade Association (NAFTA) in 1994. At the Miami Summit in 1994, countries of the Western Hemisphere announced the plan to create a Free Trade Areas of America (FTAA). The Summit brought together 34 Hemispheric Heads of State who agreed to create a free trade area encompassing the entire continent (Cuba is excluded for political reasons) and to complete negotiations for the agreement by 2005. Here, it is worth mentioning that the Uruguay Round trade talks concluded in 1994 and a decision was taken to establish the WTO with effect from January 1995.

When and if completed, the FTAA will be an extremely significant regional trading block comprising 34 developed and developing countries with a population of 750 million and a total income of nearly US\$9 trillion.

The post-Uruguay Round has also seen the further widening and deepening of the European Union. The EU has widened the integration through the Single European Act (SEA) and the Maastricht Treaty. Portugal and Spain joined in 1986 and some of the European Free Trade Area countries - Sweden, Finland, and Austria became members in 1995. Now, under the new expansion plan, the EU-15 will soon become EU-25.

\footnotetext{
${ }^{3}$ In this estimate, all types of regional agreements are included: bilateral, plurilateral and preferential nonreciprocal ones.
} 
As mentioned above, the third major development was the formation of Asia Pacific Economic Cooperation (APEC) in 1989, when the Uruguay Round of trade negotiation was at its peak. Started with 12 members in 1989, today APEC has 21 members - referred to as "Member Economies" - which account for more than 2.5 billion people, a combined GDP of US\$19trillion and 47 per cent of world trade ${ }^{4}$.

Until 1994, APEC remained a loose consultative forum with no ambition of creating yet another trading block. At their second APEC leaders meeting in November 1994 in Bogor, Indonesia, however, the 18 participating leaders declared their intention of turning APEC into a zone of free trade and investment by 2010, for APEC's developed economies, and by 2020 for its developing members.

\section{III.2 South-South Preferential Trade Agreements}

The new upsurge in RTAs not only resulted in qualitative and quantitative changes in regional integration involving North-North and North-South countries, but it has also ignited many Southern countries to work for free trade areas among themselves. In 1980s, attempts at regional integration were made in Latin America, Africa, and Asia with renewed vigour. In 1980s and 1990s, many Southern countries underwent a period of structural adjustment and economic reform.

In Latin America, MERCOSUR (the Common Market of the South) was formed in 1991 and the Group of Three in 1995. The Andean Pact and Central American Common Market (CACM) were resurrected in 1991 and 1993, respectively. According to some estimates, between 1990 and 1994 alone, 26 bilateral and regional trade agreements were signed among Latin American countries ${ }^{5}$.

In Sub-Saharan Africa, the blocks in West Africa were reformed and reorganised. The Southern African Development Community (SADC) developed out of an earlier defencebased organisation, Southern African Development Coordination Conference, and was supplemented - for many of its members - by Cross Border Initiative (CBI). The East African Cooperation sprang up where the East African Community had failed.

The Middle East witnessed the development of the Gulf Cooperation Council, and in 1997 Arab League members agreed to cut trade barriers over a 10-year period. In Asia, the Association of South-East Asian Nations (ASEAN) countries developed 25 years of political cooperation into a free trade area in 1992, with the formation of the ASEAN Free Trade Area (AFTA).

\section{III.3 Preferential Trade Agreement in South Asia}

The South Asian Association for Regional Cooperation (SAARC) was formed in 1985 as a political consultation entity. In its first year of existence, it had little success in promoting trade preferences among its members. Though the plan to create the South Asian Preferential Trade Area (SAPTA) was announced in 1993, the actual exchange of preferences remained extremely limited (Panagariya, 2002).

\footnotetext{
${ }^{4}$ http://www.apecsec.org.sg/apec/about_apec.html , website visited on $20^{\text {th }}$ November 2003.

5http://www1.worldbank.org/wbiep/trade/RI_map.html, website visited on $18^{\text {th }}$ May 2001.
} 
The SAPTA framework provides for periodic rounds of trade negotiations for the exchange of trade concessions on tariff, para-tariff and non-tariff measures using a combination of negotiating approaches. In view of the modest progress made in the initial years, the deadline for a free trade area, which was finally envisaged for 2001-2005, has been postponed to 2008 for non-LDC members (India, Pakistan and Sri Lanka) and 2010 for LDC members (Bangladesh, Bhutan, Nepal and Maldives).

A major breakthrough, however, was made in January 2004 when during the $12^{\text {th }}$ SAARC Summit, held at Islamabad, an agreement on South Asian Free Trade Area (SAFTA) was signed. The SAFTA agreement is slated to come into force from January 1, 2006 upon completion of formalities, including ratification by all contracting states and issuance of notification by the SAARC Secretariat. The SAFTA agreement, inter alia, includes trade facilitation measures like harmonisation of standards, reciprocal recognition of tests and accreditation of testing laboratories of contracting states and certification of products.

The signing of the SAFTA agreement is a landmark in the evolution the SAARC since its formation in 1985. It marks a movement away from the mere tinkering with tariffs under SAPTA in order to establish a free trade area in the region. The commodity-by-commodity negotiations under SAPTA were proving highly laborious and time-consuming and had hardly made any impact on the intra-regional trade, which is still languishing below five per cent of the total global trade of the SAARC member states. The SAFTA agreement has the potentiality of going beyond its stated objective of liberalisation of trade in goods. A successful integration can make South Asia a magnet for vastly enhanced foreign investment and lead to a restructuring of the economies making the region one of the fastest growing and most competitive economic blocks (Dubey, 2004).

\section{Impact of Cancun Collapse: Will RTAs Proliferate Further?}

No doubt, the world we are living in is a regionalised one. With the EU, NAFTA, APEC and MERCOSUR - just to mention a few - the global political economy is divided into regions. Already there has been a huge proliferation of RTAs in the last two decades. As regards regional trading agreements in a true sense, all possible permutations and combinations have been tried, except some pockets of East Asia involving Japan, China and Korea are still a virgin zone. Hence in the wake of Cancun collapse, the fear of its proliferation is little unwarranted. Nevertheless, the failed trade talks at Cancun may have some impact on it.

\section{IV.1 Possible Factors Influencing the Move Towards RTAs}

Firstly, the failure of multilateralism for the time being will strengthen the views of those who see regionalism being a 'stepping stone' towards multilateral trade liberalisation. The other viewpoint holds an opposite stance and sees regionalism being a 'stumbling block' with regard to globalisation. So far, this debate is rather inconclusive.

Secondly, the mandate of Doha Development Agenda on RTAs will be diluted. Para 29 of the Doha Ministerial Declaration gives the green light to negotiations aimed at clarifying and improving disciplines and procedures under existing WTO provisions applying to RTAs. RTAs in the WTO context constitute a permitted departure from the most-favoured-nation (MFN) principle, which is permitted under Article XXIV of the GATT. By their very nature, such arrangements favour imports from members of the block, and discriminate against imports from non-members. 
Thirdly, the Cancun fiasco may facilitate further deepening and widening of the existing RTAs. It is being increasingly recognised that effective integration requires more than reducing tariffs and quotas, i.e., going well beyond the stage of customs union. Many other barriers have the effect of segmenting and impending the free flow of goods, services, investments, and ideas. Therefore, wide-ranging policy measures are needed to remove these barriers. This so-called deep integration was first actively pursued in the Single Market Programme of the EU, and elements of this programme are now finding their way into the debate in other regional agreements (World Bank, 2000).

Fourthly, there are chances of proliferation of mini trading alliances, especially bilateral trade agreements. There is a concern among countries that have traditionally avoided this approach. These countries also want some cushion to fall back upon should in case the momentum of multilateralism falters. Furthermore, there is a belief in the business community that, as product cycles get shorter and multilateral negotiating cycles get longer, quicker results may be obtained regionally (OECD, 2003).

\section{IV.2 Developments in Post Cancun}

\section{IV.2.1 US' Bilateral Deals and FTAA Negotiations}

The first salvo was fired by the US Trade Representative Robert Zoellick in his $14^{\text {th }}$ September press conference, held immediately after the collapse of the Cancun Ministerial. In his post-conference press release he said that in the absence of trade liberalisation under the aegis of WTO, US would not wait but follow the path of bilateralism and regionalism. At present, the U.S. has free trade agreements with six countries, is negotiating with 14 more, and is pressing ahead to establish free trade throughout the Western Hemisphere.

After failing to prevail upon developing countries at Cancun, US then tried to dictate the agenda of VIII FTAA Ministerial meeting, held at Miami, USA (17-21 November, 2003). In order to counter the growing influence of Brazil (leader of G-22) amongst the members of FTAA, the US has announced of bilateral agreements with some member countries. Brazil has already made the US bite the dust by forcing it to drop demands for stricter patent rights and greater protection for foreign multinationals.

Brazil is also opposed to inclusion of investment, competition, and government procurement in trade agreements. However, the countries that have trade agreements with the US are - in principle - not opposed to the inclusion of these topics, since their respective treaties already include specific clauses on investment, competition policy and government procurement (ICTSD, 2003).

Taking into account of above dynamics, the US, prior to the opening of the FTAA Ministerial meeting, announced its intention to launch trade negotiations with four Andean countries and Panama. The negotiations with Columbia and Peru would start in the second half of 2004 and with Ecuador and Bolivia sometime later. Negotiations with Panama are also slated to start during the second half of 2004.

\section{IV.2.2 EU's Move: Wait and Watch}

Unlike US, the EU so far resisted the temptation to engage in bilateral free trade deals. The European Parliament in its resolution on the $5^{\text {th }}$ Ministerial Conference of the WTO has 
strongly supported multilateral trade agreements as the best mechanism for promoting free and fair trade to the benefit of all. The EU Trade Commissioner Pascal Lamy has also reiterated on several occasions that the EU looks set to remain primarily focused on multilateral trade talks at the WTO. Here, it would be worthwhile to mention that Commissioner Lamy refused to launch fresh bilateral talks after he assumed his post in 1999 .

According to a "reflection paper" being crafted by the European Commission, the EU would face a number of problems in shifting its policy toward bilateral free-trade deals. One viewpoint says that opening the EU to bilateral deals could mean it would be flooded with requests for negotiations. Such deals are hard to negotiate in a grouping of 15 nations like the EU, where individual states might have sharply different views on which countries the EU should drop trade barriers with (Miller and Newman, 2003).

However, the EU is going ahead to strike a free trade deal with the South American Mercosur trade block despite an earlier accord to delay such a treaty. The EU and Mercosur had previously agreed not to conclude an inter-regional deal before the end of the Doha round of WTO talks, which aim to finish in December 2004. But the failure of a WTO meeting in the Mexican resort city of Cancun in September has left hopes of finishing on time extremely slim. This frees ministers to cut the links with Doha.

The EU and Mercosur started talks to conclude an Association Agreement in June 1999. Since then ten rounds of negotiations have taken place. The agreement comprises three chapters: political, co-operation and trade and economic. During the 7th Round of negotiations in April 2002, the political and co-operation chapters were virtually finalised.

\section{IV.2.3 East Asia: A Virgin Zone But Slowly Gaining Momentum}

Unlike the EU and NAFTA, East Asia appears to have achieved an amazing level of economic integration without relying on an institutional framework. East Asia, excluding Japan, - namely ASEAN, China, South Korea, Taiwan and Hong Kong - sharply increased their intra-regional trade over the last two decades. In 2001, nearly 40 per cent of exports by East Asian economies were destined to the same region, up from 23 per cent in 1980. Likewise, their dependency on intra-regional trade in terms of imports 43.7 per cent in 2001 was nearly double the 22.2 per cent in 1980 . However, this figure on intra-regional trade is still far below the 61.9 per cent in EU but closing on the 46.3 per cent for NAFTA.

Over the last few years several proposals have been mooted to form a broad Free Trade Agreement involving ASEAN, Japan, China and Korea. These countries want to reduce their dependence on the United States market and also cooperate on security issues. Prime Minister Junichiro Koizumi of Japan has also put forward the proposal to create an East Asian community, which was incorporated in the Tokyo Declaration adopted at the Japan-ASEAN summit held in December 2003. The proposal called for a broad range of cooperation on the basis of the ASEAN plus Three (Japan, China and South Korea) framework, rather than specific economic integration.

The biggest developments are Tokyo's decision to join ASEAN's Treaty of Amity and Cooperation (TAC) and the commitment to create a "comprehensive economic partnership" between Japan and ASEAN, which will include elements of a free trade area, by 2012. Japan is also hoping to start formal negotiations towards bilateral trade agreements with Thailand, Malaysia and the Philippines in 2004. Bilateral working parties are compiling reports to 
assess the economic impact of trade agreements in each of the three cases. The reports are likely to conclude that further dismantling of trade barriers would be mutually beneficial.

\section{IV.2.4 South Asia: Following a Two-Track Approach}

When the Cancun Ministerial collapsed, many experts advanced the same old arguments that the inevitable consequence of not concluding multilateral trade negotiations to the satisfaction of major trading partners, is to drive them to the embrace of regional and bilateral trade arrangements. This argument is now being repeated with added emphasis that South Asia, especially India, stands to lose most heavily because of its not being a member of a regional or bilateral trade arrangement with developed countries.

Irrespective of the situation that may emerge after the collapse of Cancun trade talks, India has followed a two-track approach over the last few years. On the one hand, India is actively trying to influence the WTO trade negotiations, while on the other, it has been involved in bilateral and regional trade negotiations too. Prior to Cancun Ministerial, India signed a framework trade agreement with the Mercosur trade block of Latin America. This sets in motion the process that will ultimately establish a 'Free Trade Area' between India and Mercosur.

After Cancun, India signed free trade agreements with Singapore and Thailand (both ASEAN members). Following this is a similar agreement among China, Japan and India to create a broad East Asian group. India is also in the process of signing a PTA/FTA with Egypt.

As regards other SAARC countries, recently Bangladesh and Pakistan have reached on an overall framework on the proposed FTA. Islamabad had consented to Dhaka's request to give her special trade preference under an FTA. Bangladesh also sought a longer time than Pakistan to phase out tariff under FTA and immediate free entry of its products to the Pakistani market. However, Bangladesh has reiterated that it would not have such an agreement with India if New Delhi fails to remove various trade barriers. Besides, Pakistan is also set to sign a FTA with Iran.

In South Asia, an agreement giving effect to South Asian Free Trade Area was signed in January 2004 at Islamabad, which has already been discussed in Section III.3.

\section{Intra-SAARC Trade: Why it is Low?}

It is often argued that the intra-regional trade within SAARC countries is too low. In 2001, the intra-regional trade was only 4.9 per cent of the total trade (with members and nonmembers) of the SAARC countries (WTO, 2003). Results of the gravity model show SAPTA so far is a no block. Estimates show that trade between India and Pakistan is 70 per cent lower than two otherwise identical economies (Frankel, 1997; Frankel and Wei, 1997). However, from the sub-regional economic perspective this conclusion is a bit ironic because several studies have established that SAARC countries can benefit enormously by cooperating economically and promoting regional trade (Srinivasan and Canonero, 1993, 1995).

Several arguments have been advanced for low regional trade among South Asian countries. One very common argument is the lack of trade complementarities. The South Asian countries export labour intensive products in which they have a better comparative advantage 
in relation to the rest of the world (ROW). The volume of trade and the economic benefits from trading these products among themselves are limited. But there is a counter argument as well, saying, there is no hard evidence to endorse the argument of lack of complementarities. Many experts feel otherwise and argue that there is a need of proper research to find trade complementarities.

Services trade, however, may provide a better scope to find trade complementarities among the South Asian countries. In the social sectors like health and education, there is a considerable opportunity of increasing intra-SAARC trade. Moreover, SAARC countries are vocal on their demand for greater liberalisation of trade in services under mode 4 of General Agreement on Trade in Services (GATS). In order to counter it, developed countries, often, raise the issue of poor mobility of labour within South Asia itself. If India, who is a major demandeur of mode 4 liberalisation, demands their workers to move freely to developed countries then why it does not work for free movement of labour in its own region. Thus, if we have a greater mobility of labour within SAARC, it can be a stepping-stone in seeking greater market access for our labour in North.

Secondly, the reason for low intra-regional trade until recently was not the absence of trade preferences but the lack of liberal trade policies in general. Once the countries in the region began to liberalise, their intra-regional trade expanded rapidly, which is very much evident from the data. In 1990, share of intra-regional trade was only 3.2 per cent, which has increased to 4.9 per cent in 2001 (WTO, 2003). It is noteworthy here that India, the largest economy of this region, embarked on the trade liberalisation path in 1991 in a big way.

Thirdly, various studies show that a huge amount of border trade is taking place between the South Asian countries that remains unrecorded. Between several pairs of countries, such informal trade is considerably higher than the official trade flows. These informal trade flows are taking place not only to evade the high tariffs that must be paid on official trade, but also to carry out some trade that would have not been permitted at all. Hence, if we take into account such trade flows, intra-SAARC trade as a proportion of total SAARC trade would be higher than the estimates arrived at with the help of official trade statistics.

\section{Intra-regional Trade: A Comparison of SAPTA with Other Southern RTAs}

Over the years a number of initiatives have been taken by the South Asian countries to liberalise intra-regional trade at unilateral, bilateral and regional levels. Despite these initiatives the proportion of regional trade and investments is still quite modest. On the other hand some other South-South regional integration have done exceedingly well in terms of promoting their intra-regional trade.

In Table 1, a comparison has been made between various Southern RTAs. All these RTAs have been formed over the last two decades. South Asia has the lowest level of intra-regional trade among all. ASEAN and Mercosur have done extremely well by increasing their share to 22.4 and 20.8 per cent respectively in 2001. Even the African RTAs, all of which were formed in 1990s, have done reasonably well in promoting their intra-regional trade. 
Table 1

Intra-Regional Export Shares: A Comparison of SAARC with other Southern RTAs

\begin{tabular}{|l|l|l|l|}
\hline \multicolumn{2}{|l|}{1990} & 2001 & Year in force \\
\hline Latin America & 4.2 & 11.2 & 1988 \\
\hline Andean Group & 8.9 & 20.8 & 1991 \\
\hline Mercosur & 6.3 & 5.2 & 1994 \\
\hline Africa & 3.1 & 10.9 & 1992 \\
\hline COMESA* & 12.1 & 13.5 & 2000 \\
\hline SADC** & 19.0 & 22.4 & 1992 \\
\hline UEMOA & 3.2 & 4.9 & 1985 \\
\hline Asia & \multicolumn{5}{|l|}{} \\
\hline ASEAN/AFTA & \multicolumn{1}{|l|}{} \\
\hline SAARC &
\end{tabular}

* Prior to 2000, data unavailable for Namibia and Swaziland

** Prior to 2000, data unavailable for Botswana, Lesotho and Swaziland

Sources: UNCTAD, Handbook of Statistics 2002; WTO, International Trade Statistics 2002.

\section{South Asia: Possible Options in Post-Cancun}

The above analysis suggests that whether it is good or bad, along with the increased global integration, regionalism was on the rise during the 1990s and in all probability it will grow further, may be not necessarily in numbers but definitely in quality. As mentioned earlier, the new wave of regionalism has resulted in further deepening and widening of the existing RTAs.

Under the prevailing situation, the SAARC countries should continue with their two-track approach, giving primacy to promoting multilateral trade negotiations under the aegis of WTO. Since South Asian countries are still marginal players in global trade, the benefits out of multilateral agreements would be definitely larger than bilateral/regional trade treaties. Nevertheless, they should also try to work for meaningful PTAs/FTAs. As the current wave of regionalism has touched almost all the members of the WTO, South Asian countries cannot afford to flow against the stream.

At present, the intra-regional trade in South Asia is very low, but it would be still beneficial if they work for deeper integration as these days regionalism goes well beyond cooperation on trade front alone. Moreover, the official trade data does not reflect the true picture, as a significant amount of trade is also taking place through informal channels. There are a few very successful examples of economic integration in Southern countries. South Asia can follow the pattern of ASEAN/AFTA and Mercosur, the two successful South-South RTAs.

Lastly, one more pertinent question arises, whether South Asia should go for RTAs with developed countries or try to explore the possibility of forming South-South RTAs, especially with East Asian countries. Developed countries, like the US and the EU have traditionally been the major trading partners of South Asian countries. One viewpoint says that it would be unwise to go for such trade treaties, as these markets are relatively more open and signing bilateral trade treaties would be tantamount to giving market access to them to relatively more protected South Asian economies.

Hence, South Asian countries can follow the "Look East” policy. India has already started making efforts in this direction. After Cancun Ministerial, India signed framework agreements with Thailand and ASEAN for their proposed FTAs. 


\section{References}

Dubey, Muchkund (2004), “SAFTA: A Perspective”, The Hindu, January 10, 2004, New Delhi.

Frankel, Jeffrey (1997). “Regional Trading Blocks in the World Economic System”, Institute of International Economics, Washington DC.

and S. J. Wei (1997). “The New Regionalism and Asia: Impact and Options”, N. P. Rao and A. Panagariya (eds) The Global Trading System and Developing Asia, Oxford University Press, Hong Kong.

ICTSD (2003). “Bridges Miami Daily Update on the VIII FTAA Ministerial Meeting”, International Centre for Trade and Sustainable Development, Geneva

Limao, Nuno (2002). “Are Preferential Trade Agreements with Non-Trade Objectives a Stumbling Block for Multilateral Liberalisation?”, University of Maryland, USA.

Miller, Scott and Matthew Newman (2003). "EU Unlikely to Switch to Bilateral Deals”, Wall Street Journal as published in Financial Express on $8^{\text {th }}$ November 2003, India.

OECD (2003). "Regionalism and the Multilateral Trading System”, Policy Brief, Organisation for Economic Co-operation and Development.

Panagariya, A. (2002). “South Asia: Does Preferential Trade Liberalisation Make Sense?”, University of Maryland, USA.

Srinivasan, T. N. and G. Canonero (1993). "Preferential Trading Arrangements: Estimating the Effects on South Asian Countries”, Yale University and the World Bank.

Empirics and Policy”, Yale University and the World Bank.

(1995). "Preferential Trading Arrangements in South Asia: Theory,

World Bank (2000). “World Development Report 1999/2000, The World Bank, Washington D.C.

(2000). "Regional Integration Agreements”, The World Bank, Washington DC.

WTO (2002). “International Trade Statistics 2002”, World Trade Organisation, Geneva.

(2003). “World Trade Report 2003”, World Trade Organisation, Geneva 